SEFAD, 2020; (43): 69-82

e-ISSN: 2458-908X

DOI Number: https://doi.org/10.21497/sefad.755508

\title{
Philippe Claudel'in Bay Linh ve Torunu Romanında Zamanötesi ve Uzamötesi Anlatı*
}

\author{
Dr. Öğr. Üyesi Bülent Çă̆lakpınar** \\ İstanbul Üniversitesi, Edebiyat Fakültesi \\ Batı Dilleri ve Edebiyatları Bölümü \\ bcaglakpinar@gmail.com
}

Öz

$\mathrm{Bu}$ çalışmanın bütüncesi çağdaş Fransız romancı Philippe Claudel'in göç, sürgün, travma ve arkadaşlık temalarının işlendiği Bay Linh ve Torunu romanından oluşur. Adı geçen eser bebek torunu hariç ailesinin tamamını kaybeden yaşlı bir adamın dilini bile bilmediği bir yere göç etmesini ve burada yaşadıklarını konu edinir. Torunu için hayata tutunmaya devam eden Bay Linh'in yaşadıkları hikâye dışı üçüncü tekil anlatıcı tarafından aktarılır. Baş kahramanın yaşam izlencesinden yola çıkarak gerçek ve kurmaca ilişkisi romanda "gizlenen" ve "gösterilen" ikilisi üzerinden irdelenir. Anlatıcının romanın sonuna kadar anahtar ögelerden birini gizleyerek oluşturduğu beklenmedik son, okuyucunun bilincinde metnin yeniden anlamlandırma sürecine başlamasına zemin hazırlar. Bununla birlikte hikâye evreninin kesin olmayan zaman ve yer belirteçlerinden oluşturulduğu eser, olayların bir yere ya da bir zamana indirgenmeden ortak bir bilince hitap etmesine imkân sağlar. Karakter isimlerinin sınırlı kullanımı da bu durumu destekler. Söz konusu zamansal ve uzamsal çerçevenin belirsiz bırakılması anlatının zamanötesi ve uzamötesi bir yapıya bürünerek belirli bir kesimin değil ortak bir belleğin gerçekliğini yansıtan bir roman olarak değerlendirilmesini sağlar. Bu çalışmada Bay Linh ve Torunu romanının anlatı evrenine ışık tutmak ve roman kurgusunu ortaya koymak için eser, anlatıbilim, gerçeklik etkisi bakış açıları ve kurmaca kuramları ışığında ele alınır. Makalede anlatıının güvenilmezliği, kurmacanın gerçeklik özelliği ve anlatının zamansal/uzamsal çerçevesinin anonimleşmesi konularının incelenmesi amaçlanır. Belirtilen ögelerin üzerinde durulduğu incelemede metod olarak "olası dünyalar" ve "gerçeklik etkisi" temel alınır. Nitel bir araştırma kapsamında yazılı dökümanların analizi yöntemi izlenerek yorumlayıcı bir çalışma ortaya konulur.

Anahtar Kelimeler: Göç, sürgün, güvenilmez anlatıcı, uzamsal-zamansal çerçeve, kurmaca.

\footnotetext{
* Bu makale, 7-8 Mart 2019 tarihlerinde Galatasaray Üniversitesi tarafından düzenlenen XIV. Ulusal Frankofoni Kongresi'nde bildiri olarak sunulan metnin genişletilmiş ve düzeltilmiş halidir.

** Chercheur postdoctoral à l'Université Paris Diderot - Paris VII dans le cadre de programme international de bourses de recherches postdoctorales (2219) financé par le TUBITAK. 


\title{
Transtemporal and Transspatial Narrative in Philippe Claudel's Monsieur Linh and his Child
}

\begin{abstract}
The corpus of this work consists of the contemporary French novelist Philippe Claudel's book named Monsieur Linh and his child which focuses on the themes of migration, exile, trauma and friendship. In this book, the emigration of an old man who lost his entire family except his baby grandson, to a place where he does not even know its tongue and his experiences are discussed. The events that happen to Mr. Linh who hold on to life for his grandson are narrated by a third singular narrator. Focusing on the protagonist's life, the relationship between reality and fiction is examined through the pair that is "hidden" and "shown" in the novel. Concealing one of the key elements until the end of the novel, the unexpected end of the narrator paves the way for the reader to begin the process of reunderstanding the text. However, the story universe of the novel is composed of uncertain time and place markers and this allows the events to address a common consciousness without being reduced to a place or a time. The limited use of character names also supports this notion. Suspending the temporal and spatial framework indefinitely enables the narrative, which transforms into a trans-temporal and trans-spatial structure, to be considered as a novel that reflects the reality of a common memory, not a particular segment. In this study, in order to shed light on the narrative universe of $M r$. Linh and his child and to reveal the fiction of the novel, it is aimed to discuss the work within the scope of narrative, reality effect perspectives and fiction theories. The objective of this article is to examine the narrator's unreliability, the realistic feature of fiction, and the anonymization of the temporal / spatial framework of the narrative. In the study which emphasizes the mentioned elements, "possible worlds" and "reality effect" are taken as the basis methods. Within the scope of a qualitative research, an interpretive study is created by following the analysis method of written documents.
\end{abstract}

Keywords: Migration, exile, unreliable narrator, spatio-temporal framework, fiction. 


\section{GíRIŞ}

Roman Bay Linh adında yaşlı bir adamın ülkesini savaş yüzünden terk ederek yeni bir ülkeye göç etmesini konu edinir. Bay Linh köyüne düzenlenen bir saldırıdan sonra evine döndügünde küçük torunu hariç tüm ailesinin öldüğünü görür. Torununu da alarak savaştan kaçmak ve yeni bir hayat kurabilmek için kendisi gibi bu felaketin kurbanı olan diğer mağdurlarla beraber bir gemiye binerek ana yurdunu terk eder. Aslında bu terk edişin sebebi yaşlı adamın kendini kurtarmak istemesi değil hayatta kalan tek yakınına, yani torununa, iyi imkânlar sunarak güzel bir yaşama sahip olmasını istemesidir. Uzun ve yorucu bir yolculuktan sonra yaşamlarını sürdürecekleri ülkeye ayak basarlar. Ailesini vuran felaketten dolayı zaten bitap ve mutsuz olan Bay Linh keşfetmeye çalıştığı yeni ülkenin önüne koyduğu engelleri aşmaya ve oraya uyum sağlamaya çalışır.

Romanda savaş şartlarının ana karakteri göç etmek zorunda bırakması ve kahramanın yeni ortama uyum sağlamak için gösterdiği mücadele romanın ana izlekleri olarak ortaya çıkar. Söz konusu ana izlekleri karşılaşılan kültürel farklılıklar, diğer göç edenlerin onu dışlaması sebebiyle yaşadığı yalnızlık, vatanına duyduğu özlem, savaştan uzak olmasına rağmen hafızasında kalan kötü anılar ve ailesini kaybetmenin yaşattığı mutsuzluk yoğun bir biçimde destekler. Bu olumsuz koşullarda Bay Linh'i ayakta tutan ve ona devam etme cesareti veren iki önemli unsur bulunur. Bunlardan ilki, torunuyla ilgilenme görevidir. Onun başına bir şey gelmemesi için tüm gücüyle mücadele eder. Diğeri ise bu yabancı topraklarda dilini bile bilmeden anlaşmaya çalıştı̆̆ 1 ve daha sonra tek arkadaşı olacak Bay Bark'tır. Kaldığı yatakhaneden çıkmasını sağlayacak motive edici ögelerin başında bu arkadaşlık gelir. Bay Linh daha sonra birtakım işlere girişme cesaretini de bu adamdan alır. Çünkü Bay Bark başkahramanın torunu dışında bir bağ kurabildiği tek kişidir.

Göç, sürgün, köklerinden ayrılma ve arkadaşlık gibi evrensel konuları ele alan yapıt belirli bir savaşa ya da ülkeye ait durumu anlatan bir metin değil, aksine bu kavramları sıradan bir insanın hikâyesi üzerinden simgeleştiren, yani bireysellikten kolektife ulaşan bir esere dönüşür. Anlatıcı yaşadığı yeri bir felaket sonucunda bırakmak zorunda kalan bir kişinin kendini nasıl hissettiğini, nelere bağlandığını ve hangi sorunlarla mücadele ettiğini gözler önüne serer.

\section{KURMACA GERÇEKLIIK YA DA GERÇEĞİN KURMACASI}

Kimliği hakkında herhangi bir bilginin olmadığı anonim anlatıcl, ana karakterin ülkesini terk etmesinden başlayarak başına gelen olayları okuyucuya aktarır. Anlatıcı hikâyeyi doğrudan olaylar (in medias res) ile başlatır. Bay Linh bebek torunu ile bir gemiye biner ve uzun süre güvertede kalarak terk etmek zorunda kaldığı ülkesine bakar. Yolculuk süresince görevliler onu her defasında kamarasına götürse bile ülkesinden son bir iz görmek umuduyla ilk firsatta güverteye gelerek ufku izler. Okuyucu bir anda kendini Bay Linh ve torunu ile yolculuk yaparken bulur.

Doğrudan olaylar (in medias res) tercihi ayn zamanda başlangıcı da gizlemenin bir yoludur. Illk cümle, yaşanmaya devam edilen bir hayatın ortasından alınmış bir parçaya ait olduğu izlenimini vermeye çalışır, boş bir sayfa ile başlatılan anlatı söz konusu değildir. (Rullier-Theureut, 2001, s. 60) ${ }^{1}$

\footnotetext{
${ }^{1}$ Kuramsal metinlerden yapılan alıntılar tarafımızdan Türkçeye aktarılmıştır, verilen sayfa bilgileri orjinal dildeki yerini işaret eder.
}

SEFAD, 2020; (43): 69-82 
Bay Linh'i bu yolculuğa iten olay romanın başında gizlenir, okuyucuya bu bilgi anlatıcının geçmişe dönerek başkahramanın köyüne yaptığı saldırıyı anlatmasıyla ortaya çıkar. Geleneksel romanın aksine roman direkt olarak olayların ortasından başlar, romansal dekoru sağlayan yer ve zaman, hatta karakterlere dair bilgiler roman ilerledikçe yavaş yavaş aktarilır.

Ele aldığımız roman eşit olmayan ve numaralandırılmamış veya alt başlığı olmayan toplam yirmi üç bölümden oluşur. Roman kurgusu açısından bu yirmi üç parça beş ana bölümde yer alır. Bu durum Jean-Michel Adam'ın ortaya koyduğu anlatı şemasına (1987, s. 82) göre şu şekilde gösterilebilir.

\begin{tabular}{|c|c|c|c|c|c|}
\hline $\begin{array}{l}\text { Anlatı } \\
\text { Şeması }\end{array}$ & $\begin{array}{l}\text { Başlangiç } \\
\text { Durumu }\end{array}$ & $\begin{array}{c}\text { Harekete } \\
\text { Geçiren } \\
\text { Öge }\end{array}$ & Olaylar & Çözüm & $\begin{array}{l}\text { Sonuç } \\
\text { Durumu }\end{array}$ \\
\hline İçerik & $\begin{array}{l}\text { Gemide } \\
\text { yolculuk }\end{array}$ & $\begin{array}{l}\text { Savaşın } \\
\text { ailesini } \\
\text { yok } \\
\text { etmesi }\end{array}$ & $\begin{array}{l}\text { Mültecilerin kaldığı } \\
\text { yatakhane } \\
\text { Bay Bark ile tanışması ve } \\
\text { beraber geçirdikleri } \\
\text { günler } \\
\text { Akıl hastanesi günleri } \\
\text { Akıl hastanesinden kaçış }\end{array}$ & $\begin{array}{l}\text { Kaçtıktan } \\
\text { sonra Bay } \\
\text { Bark'1 } \\
\text { bulması }\end{array}$ & $\begin{array}{l}\text { Arkadaşına } \\
\text { kavuşması }\end{array}$ \\
\hline Bölümler & $\begin{array}{c}1 . \\
\text { bölümün } \\
\text { başı }\end{array}$ & $\begin{array}{c}1 . \\
\text { bölümün } \\
\text { son kısmı } \\
-2\end{array}$ & $3-21$ & $\begin{array}{c}21 . \\
\text { bölümün } \\
\text { sonu - } 23\end{array}$ & $\begin{array}{c}23 . \\
\text { bölümün } \\
\text { sonu }\end{array}$ \\
\hline
\end{tabular}

Tablo 1: Anlatı şeması

Anlatının temel yapısı bu şekilde tablo haline getirilebilir, ancak hikâyenin özellikle doğrudan olayla başlayan (in medias res) özelliğinden dolayı başlangıç durumu ve harekete geçiren öge farklı bir konumda bulunur. Çünkü kahramanın gemide yolculuk etmesi bir öge tarafından harekete geçirilmesinin sonucudur. Kuşkusuz bu savaş unsurudur. Anlatıcı önce kahramanın gemide altı haftalık torunu ile olan yolculuğunu anlatır, daha sonra ise onları bu yolculuğa iten trajediye değinir.

Anlatıcının doğrudan olaylar ile başlaması bu olayların bir öncesi, daha büyük bir parçanın kesiti olduğunu gösterir. Rullier-Theuret'nin belirttiği gibi hikâyenin başlangıcı bu şekilde gizlenmiştir. Bu durum okuyucuyu bir taraftan bilişsel düzeyde öncesinde neler olduğunu düşünmeye iterken diğer taraftan ise ona üst anlatı düzeyinde yeni bir rol kazandırır. Çünkü okuyucu devingen yapıdaki kurgunun parçası haline gelir. Anlatının dinamik yapısı içerisinde tamamlayıcı bilgiler Barthes'in terimiyle "sporadique" olarak bulunur, yani anlatıcı bu bilgileri düzensiz veya belirli bir sistemi olmadan farklı zamanlarda/durumlarda anlatısına katar. Okuyucu ise bu bilgileri kafasında yarattığı kurgunun eksikliklerini tamamlamak için kullanır.

Başkahraman ve torunu altı hafta süren deniz yolculuğundan sonra adını, dilini ve kültürünü bilmediği bir ülkeye varır. Önceleri mültecilerin geçici olarak kaldığı bir yatakhanede başka ailelerle birlikte kalmaya başlar. Yeni bir yere gelmenin verdiği çekingenlik ve ailesinin yok olmasının yarattığı travma yüzünden yetkililerin onu dışarıya 
çıkmaya teşvik etmesine kadar Bay Linh yatakhaneyi asla terk etmez. Dışarı çıktığında ise yol boyu ilerlediği caddede hiç karşıdan karşıya geçmeden aynı rotada gidip gelir.

Bay Linh hiç kaldırım değgistirmeden, dümdüz burnunun doğrultusunda yürüyor. Asla kaldırım değiştirmeyeceğini söylüyor kendi kendine, bu sayede asla kaybolmayacak. Yatakhanenin yer aldığı binayı bulması için geri dönüp yürümesi yetecek. (Claudel, 2007, s. 17.)

Öyle ki bir parkın önüne gelip oturduğunda kaybolacağı düşüncesiyle yolun diğer tarafına ulaşarak parka girme fikrinden sakınır. Oradaki bir banka oturarak etrafı seyretmeye, torunuyla ilgilenmeye koyulur. Bu geziler sırasında Bay Bark ile tanışır. Aynı dili konuşmamalarına ve birbirlerini tam olarak anlamamalarına rağmen aralarında bir paylaşım olur. Devam eden günlerde anlatı tekrar eden bir yapıya bürünür. Bay Linh torununu sıkıca giydirir, her zamanki yolu takip ederek parkın önündeki banka ulaşır, Bay Bark ile zaman geçirir ve tekrar yatakhaneye döner.

Bay Linh aniden sırada yalnız olmadıkların fark ediyor: bir adam yanlarına oturmuş, hem ona bakıyor, hem de küçük kıza. Bay Linh'le hemen hemen aynı yaşlarda olmal, biraz daha genç de olabilir. Biraz daha uzun boylu, biraz daha şişman ve üzerinde daha az giysi var. Adam gülümsüyor. (Claudel, 2007, s. 21)

Bay Linh ve Bay Bark'ı birbirlerine yakınlaştıran belki de yaşadıkları olayların benzerliğidir. Hikâyenin kahramanı tüm ailesini köyüne yapılan saldırı sonrasında kaybeder, geride kalan son kişi olan torununa tutunur. Bay Bark ise karısını kaybettikten sonra yalnız kalır, bir türlü bu durumu aşamaz. Bu yalnızlık duygusu iki adamı birbirine yaklaştırır ve aralarında güçlü bir arkadaşlık duygusu oluşturur. Bu devam eden olaylar zinciri Bay Linh'in yatakhaneden çıkarılarak başka bir yerde kalmasına karar verilene kadar devam eder. Bu kararı öğrendiği ilk andan itibaren Bay Linh'in aklında arkadaşını bir daha bulamama endişesi vardır. Çünkü o zamana kadar hiç farklı bir yere gitmez, hep aynı yoldan hep aynı yere ulaşır.

Anlatıcı, kahramanın kaldığı yeni yeri doğrudan belirtmek yerine dolaylı olarak okuyucuya sezdirir. Nereye yerleştirildiğini açıkça ifade etmeden, kahramanın yeni kalacağı yeri keşfetmesine okuyucun da eşlik etmesini sağlar. Okuyucunun üstlendiği bu görev birçok kuramcı tarafından farklı terimlerle ifade edilir. Riffaterre üstokur (archilecteur), Eco örnek okur (lecteur modèle) ya da Iser örtük okur (lecteur implicite) kavramlarıyla ayn çizgide yer alarak okuyucunun metnin anlamlandırılmasındaki kilit önemini ortaya koyarlar. Aralarında bazı farklılıklar olsa da temelde birleşen araştırmacılar, okuma eyleminin metnin izin verdiği ve okurun bireyselliğine dayanan olmak üzere iki düzlemde gerçekleştiğini savunur. Bu durumu destekleyen Vincent Jouve iki boyutu şu şekilde açiklar: "[...] her zaman iki boyut vardır: biri tüm okuyucular için ortaktır, çünkü metin tarafından belirlenir, diğeri sonsuz değişkendir, çünkü her bireyin metin üzerine ne yansıttığına bağlıdır" (Jouve, 1993, s. 94). Eco'nun belirttiği gibi "bir metnin potansiyel içeriğinde tam olarak deşifre olması için" (1985, s. 77) okuyucunun belirli yorumlayıcı eylemleri gerçekleştirmesi gerekir. Dolayısıyla ele aldığımız romanda da okuyucuyu bilişsel düzeyde daha aktif olmaya iten bir anlatı mekanizması bulunur. Anlatıcı bazı olayları geçiştirerek, bazılarını atlayarak ya da belli belirsiz bir biçimde aktararak hikâyenin ikincil bir anlamlandırmaya olanak tanıacak biçimde sonuçlanmasını sağlar. Buna en önemli örnek olarak başkahramanın kaldığı iki binanın açık biçimde ifade edilmeden sadece yaşananlar üzerinden okuyucuya betimlenmesi verilebilir. Bir nevi okuyucu başkahramanla beraber nerede olduğunu 
anlamaya ve insanların hareketlerine anlam verme çabasına girer. Çünkü anlatıcı, okuycunun bu yerleri Bay Linh ile birlikte keşfetmesini sağlar.

Rıhtımdaki Kadın koluna girip onu içeriye sokuyor. Giriş çok büyük, dev gibi. Bir adam onları karşılamaya geliyor, kadın ona Bay Linh'i göstererek açıklamalarda bulunuyor. Bir köşede, saksı içinde bir palmiye var. Bir başka köşede, kalın mavi kumaştan sabahlıklar giymiş üç yaşlı adam. Koltuklara oturmuşlar ve Bay Linh'e bakıyorlar. Gözleri ölü gibi görünüyor. Onlardaki her şey ölü gibi görünüyor. (Claudel, 2007, s. 77-78)

Gün battığında beyazlı kadın yeniden onu görmeye geliyor. Bir pijamayla mavi bir sabahlık getiriyor. Bu giysileri giymesi gerektiğini anlatıyor. Kollarım kavuşturarak bekliyor. Bay Linh torununu yatağa bırakıyor ve tuvalete giriyor. Pijamayı giyiyor, sabahlı̆̆ı sırtına geçiriyor. Sabahlık bayağı büyük geliyor. Neredeyse yerleri süpürecek. Tuhaf bir giysi. (Claudel, 2007, s. 81)

İlk başta huzurevi gibi görünen yerin Bay Linh'in dışarı çıkmaya çabalamasından sonra bir hastane olduğu anlaşılır. Bu durum hem olayın kahramanı açısından, yani hikâye evreni çerçevesinde (diégèse), hem de okuyucu açısından mantıklı bir açılaması yoktur. Burada yarı tutsaklık yaşayan Bay Linh arkadaşını tekrar görebilmek için kaçmayı göze alır. Yatakhane günlerinde kaybolmaktan korktuğu için rotasını bile değiştirmeyen kahraman, hiç bilmediği bir yerden nasıl ulaşacağını bilmediği bir yere gitme kararı alır. Dolayısıyla Bay Bark ile olan arkadaşlı̆̆ı onu harekete geçiren ya da güdüleyen öge olarak ortaya çıkar. Torununu da yanına aldıktan sonra hastaneden kaçar.

Uzun bir yürüyüşün ardından Bay Linh bitap düşer ancak kendini kaybetmeden önce arkadaşıyla geldiği parka ulaştığını fark eder. Onu her zamanki bankta bulmanın verdiği heyecanla dikkatini kaybeder ve karşıdan karşıya geçtiği sırada bir araba ona çarpar. Bir taraftan torununu tutarken bir taraftan da kendisi rahatlatmaya çalışan arkadaşının elini tutar. Bu kavuşma anı ile romanın anlatı şeması tamamlanır.

Kahramanın ülkesine yapılan saldırada ailesini kaybetmesinin yarattığı travma hikâyenin tamamlanmasıyla daha da açık bir şekilde ortaya çıkar. Bay Linh'in yaşadığı travma, kendiyle aynı kaderi yaşayan insanlardan kendine soyutlamasıyla, sürekli kaybolacağını düşünmesiyle ve en önemlisi de romanın sonunda torunuyla ilgili gerçeğin ortaya çıkmasıyla netleşir. Ailesini tamamen kaybetmenin yarattı̆̆ı şok yüzünden gördüğü felaketi yadsır ve bilinçdışında kendine alternatif bir gerçeklik oluşturur. Anne Martine Parent bu durumu "travmatik olayın şiddet içeren veya yıkıcı doğasının ötesinde, öznenin başına ne geldiğiyle yani travmayı oluşturan şeyle kendini bütünleştirememesi olayı" (2006, s. 115) olarak açıklar. Dolayısıyla özne tam olarak ne olduğunu bilmez, şok bir şekilde felaketin üzerini örter. Yapılan çalışmalar, özellikle savaş sonrası ve Yahudi soykırımı alanlarındaki travma çalışmaları, sebeplerin farklı olması gibi sonuçların ya da etkilerin de değişiklik gösterdiğini ortaya koyar. Bay Linh'e karşı görevlilerin ve yatakhaneyi paylaştığı insanların tepkileri hep akıl sağlığını kaybettiği üzerine kuruludur.

\footnotetext{
Çocuğun altını değiştirirken ya da onu yıkarken kendini hareketketlerine kaptırdığını gören kadınlar da gülüyor zaman zaman:

'Amca, bu işten hiç anlamıyorsunuz! Bırakın da biz yapalım! Bir yerlerini kıracak değiliz ya!'

Ve daha yüksek sesle gülüyorlar. Çocuklar da gülüyor, annelerinden daha yüksek sesle. (Claudel, 2007, s. 15)
} 
Yardım etmeye çalışıyor gibi dursa da yatakhanedikiler sürekli Bay Linh ile dalga geçerek onun daha da içine kapanmasına sebep olurlar. Bu durum zaten ailesini ve yurdunu kaybettiği için üzüntülü olan kahramanın kendini daha fazla soyutlamasına, kader ortaklarından uzaklaşmasına yol açar. Bay Linh'i Bay Bark'a yakınlaştıran ise Bay Bark'ın ona karşı olan arkadaşça tavrı ve torununa gösterdiği ilgi ve özeni paylaşmasıdır.

Bay Bark'ın sayesinde yeni ülkenin bir yüzü, bir yürüme biçimi bir ağırlı̆̆ı, bir yorgunluğu ve bir gülümsemesi, hatta bir kokusu bile var, sigaraların kokusu. Şişman adam hiç farkında olmadan tüm bunları verdi Bay Linh'e. (Claudel, 2007, s. 55)

Yabancılık ve yalnızlık hislerinin ortadan kalkmasına aracılık eden bu dostu sayesinde Bay Linh yeniden mutlu hissediyor. "Onun dilini konuşmasa da, o dili anlamasa da" (a.y.) en çok hatta tek paylaşımda bulunduğu kişi arkadaşı Bay Bark'tır.

Romanın tamamında anlatıcı, sınırlı sayıda karakteri anlatısına katar. Yer isimlerini vermekten kaçarak özel bir alandan bahsetmez ve zamansal olarak kesin tarihlere yer vermez. Bay Linh'in nereden geldiği, nereye geldiği, ne zaman geldiği veya hangi savaştan kaçtığ1 roman içerisinde net bir biçimde ifade edilmez. Belirli bir coğrafyaya indirgemeyi sağlayacak yer adlarının bulunmaması, kişilerin isimlerinin neredeyse yok denecek kadar az olması (Bay Linh, Bay Bark ve Sang Diû) ve direkt zamansal belirteçlerin yer almaması anlatıyı kurmaca olarak sınıflandırmayı mümkün kılar. Ancak eser evrensel bir belleğe bilişsel düzeyde göndergeler oluşturarak hitap eder. Anlatılanlar kendi dönemini, gerçekleştiği yeri ve kişileri aşarak toplumsal boyutta bir olaya dönüşür.

Barthes kurmaca bir eserde kullanılan gerçek ögelerin eserde bir gerçeklik etkisi (effet de réel) oluşturduğunu ileri sürer: "Nihayetinde Flaubert'in barometresi, Michelet'nin küçük kapısı sadece şunu söylemektedir: Biz gerçeğiz; dolayısıyla gösterilen "gerçek" kategorisidir (muhtemel/olası içeriği değil)" (1982, p. 10). Nesneler, kişiler, yerler, sosyal, politik veya edebi olaylar, diğer bir deyişle gerçek dünyaya ait unsurların romanda kullanılması kurmacaya gerçek izlenimi verir. Ancak incelediğimiz romanda kurmacanın gerçekçiliği olayları destekleyecek gerçek elemanlarla değil anlatının bireysellikten uzaklaşarak kolektif bir yapıya bürünmesinden dolayıdır. Riffaterre'in göndergesel yanılsama (illusion référentielle) görüşü de Barthes'ın bakış açışısını tamamlar niteliktedir. Kuramcıya göre, okuyucunun kurmacayı gerçek olarak görebilmesi için anlatı dünyası dışındaki ögeler ile anlatıda yapılan göndergeler arasında bir bağ kurması gerekir (1982, s. 97-98). Çünkü anlatıcının yarattığı gerçeklik algısı okuyucunun kültürel bilgisine bağlı olarak yorumlanabilir. Bay Linh ve Torunu romanında yaşadığımız dünyaya ait durumlar ele alınır, bunların bir gerçeklik yanılsaması ya da bir tür sanal gerçeklik olarak okunması okuyucunun anlatı dünyası dışında sahip olduğu tecrübe ve bilgiyle mümkündür.

Leibniz'in din alanında ortaya attığı olası dünyalar (mondes posssibles) kuramını Thomas Pavel edebiyat incelemesine uyarlar (Pavel, 1988). Leibniz'e göre tanr1 yaratılabilecek muhtemel tüm dünyaları bilir ve aralarından en uygununu yaratır. Bu en iyi dünya olmayabilir ama olasılıklar içerisindeki en idealidir. Bu düşünceyi de piramit modeli ile ortaya koyar. Piramidin tepesinde şu an yaşadığımız dünya, aşağı doğru ise sonsuz sayıdaki ihtimaller dünyaları bulunur. Pavel ise piramidi ters çevirerek edebiyat eserlerinde oluşturulan dünyaların gerçek dünyadan birtakım elemanları alarak gerçeksel bir kurmaca olduğunu söyler. Dolayısıyla Bay Linh'in hikâyesi Pavel'in piramidinde bizim dünyamıza bir alternatif olarak yer alır.

SEFAD, 2020; (43): 69-82 
Bu iki bakış açısı, gerçeklik etkisi ve olası dünyalar, ele aldığımız romanın gerçekliğe öykünen bir anlatı yapısı oluşturduğunu ifade etmemize imkân verir. Buradaki söz konusu gerçeklik belli bir yere veya zamana ait olmaktan çok ortak belleğe göndermeler yapan bir durum gerçekliğidir. Dolayısıyla belirli zaman ve zaman belirteçlerinin eksikliği bu anlatının gerçeklik etkisini zayıflatmaz, aksine daha geniş bir hafıza anlayışına hitap eder.

Anlatının son sahnesi önemli iki noktaya ışık tutar, bunlardan birincisi anlatıcının güvenilmez olması durumu, diğeri ise romanın yeniden yorumlanmasına imkân tanıyan anlatıcının sakladığı bilgidir.

\section{ANLATICININ GÜVENİLMEZLIĞĞ YA DA SADAKATSIZZLİĞí}

Hikâye zamanına veya olayların nerede geçtiğine dair direkt bilgiler anlatı içerisinde yer almaması veya zamansal çerçeve net olarak belirtilmemekle birlikte anlatıcı olayları kronolojik olarak aktarır. Ancak bu kronolojik yapıda anlatıcı yer yer geriye dönüşler (analepse) yaparak anlatı evrenini ikincil bilgiler ile güçlendirir. Bu zamansal düzensizlikler hikâyenin temel zaman çizelgesi üzerinde çok büyük değişiklikte bulunmaz. Kahramanın geçmişine dair anılar ve vatanına duyduğu özlem genelde bu dönüşlerin konusunu oluşturur.

Anlatıcı, Bay Linh'in bir kasım günü sığındığı ülkeye vardığını belirtir, yolculuğun altı hafta sürdüğü bilgisini de paylaştığı için yolculuğun eylül veya ekim aylarında başladığ tespit edilir. Ancak zaman belirteçlerinin yarı belirli veya belirsiz olarak kullanılması hikâyeyi bir döneme ya da bir süreye indirgememizi engeller. Eserde kurmaca zamanını tam olarak ortaya çıkaracak süredizimsel (takvimsel) zaman belirteçleri çok az kullanılır. Kullanılanlar ise belli bir dönemi ya da tarihi işaret etmekten çok uzaktır. Sadece hikâyenin kronolojik sırasını takip etmeye yarayan "kasım ayında", "altı hafta sonra", "birkaç gün önce" gibi yarı belirli göndermeler bulunmaktadır. Bu durum öykü/kurmaca zamanını "zaman ötesi" bir konuma getirerek yaşanan olayların bir döneme ait olmadığını, aksine daha evrensel bir yapıda olduğunu gösterir. Anlatıcının yarattığı bu zamansal bulanıklık anlatının gerçeklik ile olan ilişkisini zayıflatmaz. Ele alınan konuyu kurmaca zamanını güçlendirecek, gerçeklikle olan ilişkisine katkıda bulanacak başka ögelerle destekler.

Anlatıcı zaman konusunda olduğu gibi uzam/mekân konusunda da direkt göndergelere başvurmaz. Bay Linh'in nereden geldiği, hangi ülkeye gittiği ya da olayların hangi şehirde geçtiği belirtilmez. Cadde, park ve bahçe gibi açık uzam terimleri ya da yatakhane, hastane ve restoran gibi kapalı uzam yapıları olayları ilişkilendirecek özel bir yeri göstermez.

Nihayet, bir kasım günü, gemi varış noktasına ulaşıyor, ama yaşh adam inmek istemiyor. (2007, s. 10)

Zaten yalnız olsaydı burada, kendi ülkesi olmayan bu ülkede de bulunmazdı. Kendi ülkesinde kalırdl. (s. 26)

Karşısında, caddenin öte tarafinda, yüzlerce aile Park'a girerken yüzlercesi dışarı çıkıyor. (s. 44)

Yaşlı adam yeniden Park'ın girişine bakıyor. Bu Park'ta aileleri böylesine çeken, böylesine harika ne olduğunu görmeyi çok isterdi. Ama orası caddenin öte tarafinda ve cadde geniş, uçsuz bucaksız, korna sesleri, gri ve mavi sis dumanları arasında her iki yönde de tüm hızlarıla gidip gelen arabalarla dolu. (s. 45) 
Herhangi bir gerçek uzam göndergesi olmamasına rağmen okuyucu zihninde olayları düşsel uzamdan çıkararak gerçek uzam boyutunda algılar. Çünkü anlatıcı belirli bir zaman diliminde, belirli bir yerde belirli bir göçmenin başına gelmiş olayları anlatmaz. Göç etmek zorunda kalan insanların karşılaştıkları problemleri anonimleştirir. Bay Linh'in sunulan hayat kesiti bunu örnekleyen bir durumdur sadece. Özel yer adları ya da mekânı bir belirli noktaya sabitleyecek bir anlatımdan uzak durulur. Olayların takip sırası için zamansal belirteçler verilir ancak bunlar da hikâyenin olay sıralamasını belirlemek için kullanılır.

Romanın öyküleme zamanı artsüremsel olarak ortaya çıkar çünkü anlatıcı sıfır odaklayım ile olayları bittikten sonra aktarır. Sınırsız bakış açısına sahip anlatıcı Bay Linh'in yaşam serüvenini anlatının merkezine aldığı eserde anahtar bilgiyi romanın sonuna kadar saklar. Bu bilgiye dair destekleyici ve çürütücü unsurları satır aralarında okuyucuyla paylaşır. Okuyucunun zihninde oluşan birtakım sorular, ikilemler veya yanlış anlamalar ancak anlatıcı gerçeği net olarak gösterdiğinde cevap bulur ya da netleşir.

Bay Linh'in torunu Sang diû hiç ağlamaz, büyük babasını rahatsız etmez, hep sessiz bir şekilde tasvir edilir. Ya sakince uyurken ya usluca olanları izlerken ya da kendisine verilen yiyecekleri itiraz etmeden yerken aktarılır. Bu kadar küçük bir bebeğin hiç ağlamaması veya hiç huzursuz olmaması şüphe uyandırmasına rağmen anlatıcı dikkati başka yönlere çeker. İkinci olarak Bay Linh'in uyuyakaldığı bir sahnede beraber yaşadığ 1 diğer iki ailenin çocukları Sang Diû́yu izinsiz olarak yanından alırlar ve birbirlerine atıp tutarak oynarlar. Uyandığında bunu gören Bay Linh çok sinirlenip üzülmesine rağmen çocukların annelerinin tepkisi çok sıradandır. Bu durumlar okuyucu için bir tereddüt oluştursa da başka veriler bu tereddütlerin seviyesini azaltır.

\begin{abstract}
Uyandığında geç olmuştur. Anında bir şeylerin normal gitmediğini hissediyor. Elini uzatıyor, eli bir şeye değmiyor, sıçrayarak doğruluyor, sağına bakıyor, soluna bakıyır, Sang diû! Sang diû! Küçük kız kaybolmuş, yatakta değil, Sang diû! Karavanın çevresine toplanmış sebze ayıklayan kadınlar Bay Linh'in feryadıyla dönüp bakarlar. [...]

Aniden yatakhanenin öbür ucunda, üç çocuğu, en küçük olanların fark ediyor. Gülüyorlar. Kahkahalarla gülüyorlar. Onlarla birlikte kimi görüyor? Torununu, hiç dikkat etmeden, hiç özen göstermeden elden ele geçirdikleri, gözleri dehşetten açılıp kapanan torununu. (Claudel, 2007, s. 47)
\end{abstract}

Bebeğin uyanık ve uyumuş hallerinin anlatılması, kimsenin net olarak gerçeği açıklamaması veya Bay Bark'ın bebeğin ismini sorup daha sonra ona hediye alması söz konusu şüpheleri zayıflatır. Anlatıcı bebeğin aslında oyuncak olduğunu söylediğinde metindeki bazı parçalar farklı bir şekilde anlamlandırılır. Çocukların bebekle oynamasının sebebi yaramaz oldukları için gibi düşünülebilir, ancak bu bilgiden sonra aslında normal olduğu ve bu sebeple annelerinin tepkisinin sıradan olduğu anlaşılır.

Her şeyi bilen (omniscient) dış öyküsel anlatıcı anlatı süresince bebeğin oyuncak olduğunu gizler ve Bay Linh'in inandığı gibi hayatta kalan tek yakını olarak tanıtır. Geçmişe dönerek kahramanın torununu bulduğu bölümde herkesin öldügünü, oyuncak bebeğin patlamanın etkisiyle parçalandığını ama yanı başındaki torununun iyi olduğu söyler.

Çocuğun ebeveynleri Bay Linh'in çocukları. Çocuğun babası oğluydu. Yıllardır ülkeyi kasıp kavuran savaşta öldüler. Bir sabah, çocukla birlikte, çeltik tarlalarında çalışmaya gittiler ve akşam bir daha geri dönmediler. Yaşlı adam koştu. Soluk soluğa vardı çeltik tarlasının yakınına. Tarladan geriye dev bir çukur kalmıştı, içine şıpır şıpır suların

SEFAD, 2020; (43): 69-82 
damladığı bir çukur, kraterin bir yanında sama çöpü gibi ikiye ayrılmış boyunduruğuyla karnı parçalanmış bir manda ölüsü yatıyordu. Oğlunun bedeni de, karısınınki de oradaydı, ve biraz ileride gözleri iri iri açılmış, kundaklanmış küçük çocuk duruyordu, să̆ salim, ve çocuğun yanında bir bebek, çocuğun bebeği, patlayan bombayla başı uçmuş boyundan büyük oyuncak bir bebek. (Claudel, 2007, s. 11)

Romanın sonunda ise bu durumun tam tersi olduğu, yani aslında zarar görmeyenin oyuncak bebek olduğu ortaya çıkar. Anlatıcının dinleyiciden (narrataire) bu durumu gizlemesi verdiği bilgilerin yanlış olmasını gerektirmez. Birtakım bilgileri anlatının içerisine saklaması ya da belirsiz ipuçlarını satır aralarında vermesi arka planda çok daha büyük olayın gizlenmesi içindir. Okur/dinleyici Bay Linh'in karşılaştıklarına odaklanırken gerçekte yaşadığı travmayı ancak romanın sonunda algılamayı başarır. Anlatıcının bebeğin oyuncak olduğunu saklaması romanın sonunda okuyucu için bir şok etkisi oluşturur ve okuyucunun kafasında yarattığı hikâyeyi anlamlandırma sürecini başa döndürür. Kişilerin yaptıklarını ve söylediklerini yorumlayan okuyucu için yeni bir değerlendirme yapması gerektiği ortaya çıkar.

Diğer taraftan dış öyküsel anlatıcının sıfır odaklayım ilkesine uymadan uymayarak bu gizemi açıklamaması Gerard Genette'in paralipse² (1983, s. 44) olarak adlandırdığı duruma bir örnek olarak karşımıza çıkar, anlatıcı aktarması gereken bilgileri dinleyiciden (narrataire) / okuyucudan (lecteur) gizler. Dolayısiyla Bay Linh ve Torunu adlı romanin anonim anlatıcısının bu anlatı tekniği ile yarattığı şaşırtıcı son, eserin yeniden anlamlandırılmasına olanak sağlar.

\section{MEKÂNIN BELİRLİLIĞİ YA DA BELİRSIZZLIĞ́̇}

Göç temasının sıkı bir ilişkide bulunduğu uzam konusu anlatının alt anlamlarına ulaşılması açısından büyük bir öneme sahiptir. Bu bağlamda anlatıcı iki ana eksen üzerinde mekânı konumlandırır: Özlem duyulan vatan ve zorunlu olarak sığınılan ülke.

Kahramanın yaşadığı yere dair bilgiler anılar aracılığıyla anlatıda yer alır. Yaşanan trajedi onun torunuyla birlikte evinden uzaklaşarak yeni bir yere göç etmesine yol açar. Romanın başında artık görülmemesine rağmen Bay Linh umutla ufka bakarak ülkesini görmeyi ister. Bu ritüelini yolculuk bitinceye kadar tekrar eder. Varacağı yeri merak etmez, artık denizin ve gökyüzünün birleşerek her şeyi yok etmesine rağmen hep geldiği noktaya odaklanır. Yurdundan kopmamak için son bir çaba sarf eder, zira gemi hedefine ulaştığında ancak o zaman ülkesinden tamamen kopacağını düşünür.

Bay Linh gemiye içinde kullanılmış kıyafetler, neredeyse silinmiş bir fotoğraf ve yaşadığ1 yere ait bir poşet toprak bulunan eski ince bir valiz ile biner. Geçmişine dair tüm izler bu üç unsurda birleşir. Geleceğine dair tek öge ise uslu uslu kucağında bekleyen torunudur. Yaşadığı yeri, ailesini ve anılarını bir valize sığdırmaya çalışarak torunu için bu yolculuğu yapmak zorunda kalır.

Gemiden indiğinde ilk izlenimi bu bilinmez yerin hiç kokusunun olmamasıdır: “Hava çok soğuk. Gökyüzü kapalı. Bay Linh yeni ülkenin kokusunu soluyor. Hiçbir koku almıyor burnu. Hiçbir koku yok." (Claudel, 2007, s. 10). Hem kendini hem çocuğu rahatlatmak için

${ }^{2}$ Bu terim bir konuyu önemsiz gibi göstererek dikkat çekmeyi de ifade eder. Ancak anlatıcı söz konusu olduğunda, anlatıcının benimsediği bakış açısına göre birtakım bilgileri paylaşmama, gizleme durumudur. 
kendi dilinde bir şarkı mırıldanır. Kimsenin konuşmadığı, neredeyse heykel gibi hareket ettiği rıhtımda ilerlemek için bir güç arar.

Diğer tüm göçmenler gibi, Bay Linh kendisine söyleneni yerine getiren pasif bir yapıdadır. $O$ yüzden bir şeylere itiraz etmeden diğerleri gibi mekanik bir biçimde söylenenleri yapar. Dışarı çıkması söylediğinde istemese de çıkar ya da yerini değiştirmek istediklerinde karşı çıkamaz. Söylenenleri olduğu gibi kabul etmesi beklenir.

Bay Linh kendisine sunulan çorbayı tatsız, şehri soğuk ve rengi veya kokusu olmayan bir yer olarak görür. Bay Linh yeni şehri kendi anılarındaki köyüyle kıyaslayarak değerlendirir.

“Bildiklerine benzeyen hiçbir şey yok çevrede. Sanki ikinci kez dünyaya gelmiş gibi. [...]

Bunlara bakmak başın döndürüyor. Köyünü düşünüyor, hani insan bir düş görür de bunun bir düş mü yoksa kaybolmuş bir gerçeklik mi olduğunu tam olarak anlayamaz ya, işte öyle düşünüyor kendini." (Claudel, 2007, s. 18)

Uzaklaşan anavatan nostaljiyi, özlemi ve anıları çağrıştırır, bundan dolayı yeni şehir ruhsuz gözükür. Yaşadığı yeri düşünürken algısında gerçek duygusu güçlenirken yeni şehri düşündüğünde hayal kavramı öne çıkar. Bu yabancı ülke, anılarındaki ülkeden çok farklı, çok uzaktır. Bu olumsuz düşünce sadece Bay Bark ile tanıştıktan sonra, onun arkadaşlığı sayesinde bir nebze azalır.

İkinci ana eksen olan isimsiz bu şehirde üç mekân anlatı açısından dikkat çekicidir: Yatakhane, arkadaşı ile buluştukları bank ve akıl hastanesi.

\begin{tabular}{|c|c|c|c|}
\hline Vatanı & \multicolumn{3}{|c|}{ Yeni Ülke/Şehir } \\
\hline $\begin{array}{c}\text { Ailesiyle yaşadı̆̆ı } \\
\text { köy }\end{array}$ & Yatakhane & Bank & Akıl Hastanesi \\
\hline
\end{tabular}

Tablo 2: Uzamsal Çerçeve

Bay Linh ilk olarak başka sığınmacıların da kaldığı bir yatakhanede kalır. Dışarı çıkmasına bir engel olmamasına rağmen başına bir şey gelir diye orayı hiç terk etmez. Dışarı çımasını görevliler sağlar. Daha sonradan geçeceği akıl hastanesi ise tam tersidir, dışarı çımaması konusunda uyarılır hatta çıkma teşebbüsünde bulunduğunda engellenir. Bu anlamda yatakhane özgür olmasına izin verilen yerken hastane ise bu özgürlügü kısıtlayan yer olarak gösterilebilir. İlk başlarda yatakhaneden istemsizce çıkmasına rağmen arkadaşı ile olan buluşmaları kahramana dışarı çıkmak için bir motivasyon sağlar. İlk tanıştıkları ve sürekli buluştukları yer ise parkın karşısındaki bir banktır.

Yalnızca iki gün içinde tanıdık bir yere, döne döne akan büyük ve tuhaf bir selin ortasında tutunabileceği yüzen tahta parçasına dönüşen o straya oturuyor. (s. 31.)

Bay Linh ve Bay Bark aynı dili konuşmasalar da jest, mimik ve hareketlerle bir arkadaşlık kurarlar. Kahraman ona olan güvenini torununu kucağında sevmesine izin vererek gösterir, diğeri ise Bay Linh'i yargılamak veya geçirdiği travmayı belli edecek hareketlerden uzak durur. Aynı kültürü, aynı dili veya aynı zevkleri paylaşmasalar da iki yaşlı adam da yalnızlıklarını yok etmek için bir arayış içindedir. Bay Bark da aynı arkadaşı gibi oyuncağı gerçek kabul eder ve ona öyle davranır.

$\mathrm{Bu}$ bankta başlayan arkadaşlıkları kahramanın akıl hastanesine gitmesine kadar devam eder. Oradan kaçmasına kadar bir boşluk oluşturmasına rağmen Bay Linh'in bu banka ulaşmak için gösterdiği çaba bu arkadaşlığın ne boyutta önemli olduğunu gösterir. 
Zira geldiği köye dair hiçbir iz bulamadığı bu şehirde onun için değerli olan tek yer, hiçbir sokağını bilmediği bu yabancı şehirde tek işaret yeri bu banktır.

\section{SONUÇ}

Anlatıcı ülkesindeki savaştan kaçmak için ailesinden geriye sadece torunu kalan Bay Linh'in olaylara bakış açısını gözler önüne serer. Son sahnenin daha vurucu olmasını sağlamak için bilinçli olarak okuyucuyu ikilemde bırakır. Her şeyi bilen anlatıcı bebeğin oyuncak $^{3}$ olduğu bilgisini romanın sonunda açıklar. Sonuç sahnesi romanda karşılaşılan tüm sorulara, gizemlere cevap verecek bilgileri taşır. Şaşırtıcı son bazı pasajları ikincil bir anlamlandırmaya olanaklı kılar. Neden görevlilerin bebeği görünce tereddüt ettikleri, neden çocukların bebekle oyun oynadıkları ya da neden birden yeri değiştirilerek akıl hastanesine yattığı konuları açıklığa kavuşur.

Bay Linh göçmenleri, mültecileri ve sığınmacıları simgelerken torunu ise bu insanların tutunmaya çalıştıkları unsurları ifade eder. Anlatıcının belirli yer ve tarih vermemesi savaş ve göç kavramlarının evrensel bir boyutta olduğunun altını çizmek içindir. Kahraman, bilinmeyen bir yerden bilinmeyen bir yere, bilinmeyen bir tarihte ulaşıyor. Anlatı göçmenlerin karşılaştıkları ortak sorunlar üzerinden onların nasıl hissettiklerini okuyucuya aktarır. Ele alınan roman travma geçiren bir karakterin hayat hikâyesi olarak değil mültecilerin ortak yaşam öyküsü olarak okunur.

Uzamsal-zamansal çerçevedeki yarı belirlilik romanın gerçeklik etkisi zayıflatmak yerine onu daha evrensel bir plana taşır. Pavel'in ortaya koyduğu piramide göre, özel yer adlarının ve belirli zaman ögelerinin azlığı ya da yokluğu söz konusu anlatı evrenini göndergesel anlatı evreninden (içinde yaşadığımız dünya) uzaklaştırıyor gibi göstermesine rağmen işlenen konunun ortak bir belleğe hitap etmesi anlatıya başka bir gerçeklik boyutu katar. Anlatıcının olayları açığa çıkaracak anahtar bilgiyi gizleyerek oluşturduğu hikâyenin derin anlamı ancak ikincil bir yorumlama ile mümküdür. Çünkü sezdirilen bilgiler ya da eksiltili anlatımlar farklı değerlendirmelere sebep olurken kahramanın sıkı sıkıya bağlı olduğu çocuğun aslında oyuncak olması bu belirsizlikleri ortadan kaldırır. Okur bilişsel düzeyde hem kahramanın yaptıklarını hem diğer insanların şaşırtıcı görünen harekelerini ve tepkilerini anlamlandırır, hem de kahramanın yaşadığı travmanın gerçek boyutunu öğrenir.

Anlatıcı mekânsal-zamansal belirteçleri en aza indirgeyerek anlatının bir nevi anonimleşmesini sağlar. Zaman-mekân çerçevesinin bulanık olarak verilmesi eserin zamanötesi ya da belli bir zamana ait olmayan bir özellik kazanmasına olanak verir. Belirli bir yer ismi kullanmadan kurmaca uzama gerçek uzam özellikleri yüklenerek olayların gerçeklik düzleminde olduğu izlenimi verilir. Referans yapılan yerlerin belirsiz bırakılması okuyucunun kendi kültürel belleğine göre olayları konumlandırmasına olanak verir. $\mathrm{Bu}$ sayede hikâye belli bir mekâna yerleşeceği yerde uzamötesi ya da uzamdan bağımsız bir boyuta taşınır. Romanda adı veya yeri belli olmayan ülkeler/şehirler olmasına rağmen gerçeklikten kopmayan kendi dünyamıza yakın duran bir anlatı yapısı ortaya çıkar.

\footnotetext{
${ }^{3}$ Bebeğin oyuncak olduğu bilgisi Fransızca aslında direkt ifade edilirken (la poupée: oyuncak bebek) Türkçeye çevirisinde bu durum sezdirilmiştir. "Kara saçlı bebeği gördügünnde Bay Bark'ın yüreği hopluyor."
} 


\section{SUMMARY}

French writer Philippe Claudel's novel, Monsieur Linh and his child (La petite fille de Monsieur Linh), discusses the efforts of an old man and his grandson to hold on to life. The author emphasizes simplicity in expression by minimizing the number of characters. Aiming to escape the war in his country and seeking a better future for his grandson, Mr. Linh tries to keep pace with the new country and to create a new order there. In the story narrated by the third person narrator, the issue of friendship appears as a positive aspect, while negative themes such as migration, exile, loneliness or trauma are dominantly processed. He gets used to this new city, where he is completely a foreigner, not because of officers or other immigrants with whom he shares the same fate, but because of his only friend with whom he shares his loneliness although they do not speak the same language. The narrator, who uses semi-definite time markers to follow the chronological order of the story and general place expressions that will determine the spatial dimension throughout the narrative, makes the story anonymous. In this way, the narrative takes on a transtemporal and transspatial role without being reduced to any period or any place. Only some clues that the careful reader will reveal as a result of certain research may indicate that the story is related to the Vietnam War. Some of these clues are the name of the protagonist, the name of the grandson or the song he sings occasionally. In the qualitative study we made in the light of narratology, reality effect, and possible worlds theories, first of all we focus on the realistic function of the fiction in the story. Especially in the context of Roland Barthes and Michel Riffaterre's studies on the effect of reality, the realistic narrative structure of the fictional work is examined. Demonstrating the role of the reader is one of the elements that completes this section. Then, the narrator's handling of the key information that leads to the reinterpretation of the story is analyzed; because the baby, which is one of the basic elements of the novel, is not a real baby but just a toy. The narrator who keeps this situation hidden until the end of the story is considered as an unreliable narrator by the reader. In the last section, the issue of the locations where the events took place is both specific and uncertain. The examinations show that the places can be classified into two main categories as the homeland and the country of asylum for the protagonist. The places of the homeland are transferred to the reader through the memories with flashbacks, and the places in the new country of residence through the observations of the narrator. Three places, such as the dormitory, the bench across the park and the hospital, play important roles in the life path of the protagonist. These places are emptied of their traditional functions and the hero attaches unordinary and conflicting new meanings to them. He is free to do anything while he is in the dormitory but he does not want to go out, and on the contrary, he wants to escape although he is not allowed to go outside in the hospital. While the bench is a point fixed by him so as not to get lost, it then turns into a place he needs to find in order to reach his friend. In the study in question, the data obtained shows that thanks to the realistic structure of the novel, it is shaped as a universe closely similar to the real world. Revealing the knowledge that the baby is a toy at the end of the story causes the reader to reinterpret and make sense of the events on a cognitive level. The absence of specific place names and time structures that indicate the exact date allows the narrative to be discerned as a story that can take place anytime, anywhere, and anyplace. Therefore, the fictional work takes the real elements of the world we live in and fictionalize them in an anonymous structure in regard to temporal and spatial terms.

SEFAD, 2020; (43): 69-82 


\section{KAYNAKÇA}

Adam, J.-M. (1987). Types de séquences élémentaires. Pratiques, 56, 54-76.

Barthes, R. (1982). L'effet de réel. In collectif, Littérature et réalité (pp. 84-89). Paris : Seuil.

Claudel, P. (2005). La petite fille de Monsieur Linh. Paris : Stock. Retrieved from https://www.amazon.fr/petite-fille-Monsieur-Linh-Bleueebook/dp/B005OJ4SO6/ref=tmm_kin_swatch_0?_encoding=UTF8\&qid=\&sr=

Claudel, P. (2007). Bay Linh ve Torunu. (Illksavaş, Y. Çev.). İstanbul: Doğan.

Del Lungo, A. (1993). Pour une poétique de l'incipit. Poétique, 94, 131-152.

Eco, U. (1985). Lector in fabula ou la coopération interprétative dans les textes narratifs. Paris : Grasset.

Genette, G. (1983). Nouveau discours du récit. Paris : Seuil.

Iser, W. (1985). L'Acte de lecture. Théorie de l'effet esthétique. Bruxelles : Mardaga.

Jouve, V. (1993). La Lecture. Paris : Hachette.

Parent, A. M. (2006). Trauma, témoignage et récit : la déroute du sens. Protée, 34 (2-3), 113125. https://doi.org/10.7202/014270ar, 31.12.2019.

Pavel, T. (1988). Univers de la fiction. Paris : Seuil.

Riffaterre, M. (1982). L'illusion référentielle. In collectif, Littérature et réalité (pp. 91-118). Paris: Seuil.

Rullier-Theuret, F. (2001). Approche du roman. Paris : Hachette. 